


INSTITUT HINDU DHARMA NEGERI DENPASAR

Volume 11 Nomor 1, Maret 2020

\title{
GANESHA SEBAGAI SIMBOL PARADIGMA POSITIVISME
}

\author{
Hari Harsananda \\ Acyutananda Wayan Gaduh
}

Institut Hindu Dharma Negeri Denpasar

\begin{tabular}{|ll|}
\hline Keywords: & ABSTRACT \\
\hline Paradigm, Paositivism. & Positivism is a philosophical paradigm that \\
contributes greatly to the development of science in the & world, with many types of philosophical thinking in the \\
realm of thought, it is deemed necessary to carry out the \\
paradigm. paradigm serves to help distinguish one \\
scientific community with other scientific communities \\
There are many sciences that were born from the \\
philosophy of positivism such as mathematics, physics and \\
other natural sciences. This knowledge can be categorized \\
as hard science that formulates problems outside of \\
human beings. The existence of positivism is always \\
attached to western philosophy which is considered as the \\
forerunner to philosophy, but the positivism paradigm is \\
actually present also in the local scientific dimension, \\
namely Paradigm Ganesha as a god for posivistic \\
sciences.
\end{tabular}

\section{PENDAHULUAN}

Manusia merupakan makhluk yang berlogika dan mampu berpikir. Melalui pikirannya manusia mampu menghadapi dunia dan mampu bertahan hidup demi tetap eksis di dunia ini. Pikiran manusia juga menjadi nilai yang menjadikan manusia lebih dari makhluk ciptaan Tuhan lainnya. Kitab Sarasamuccaya sloka 4 menyatakan bahwa keutamaan menjadi manusia adalah, manusia mampu menyelamatkan dirinya sendiri dari kesengsaraan, tentunya dalam usaha penyelamatan diri, manusia tidak berdiam diri semata. Manusia melibatkan pikiran dan aksi nyata untuk itu. 
Melalui pikirannya, manusia mampu mentransformasikan hal-hal empiris menjadi pengetahuan, yang dalam kesehariannya terus bertambah dan digunakan untuk memecahkan berbagai permasalahan hidup yang dihadapi. Pengetahuan yang dimiliki manusia kemudian di transformasikan kembali pada ruang-ruang yang lebih spesifik dan terarah, hingga memunculkan ilmu pengetahuan yang secara nyata mulai mengkhusus membahas problematika manusia dari berbagai aspek kehidupannya. Manusia nyatanya dihadapkan pada dua realitas besar, yaitu problematika mengenai alam, serta problematika mengenai dirinya sendiri selaku individu dan selaku manusia yang berpikir. Maka tidak salah jika dalam perkembangan filsafat, dua realitas besar ini selalu menjadi ontologi dan menjadi titik awal berpikirnya manusia.

Atmaja (2014: 10) dalam bukunya "Saraswati dan Ganesha sebagai Simbol Paradigma Interpretativisme dan Positivisme" merumuskan bahwa dua realitas besar ini mampu menjadi dua kutub keilmuan disebut sebagai ilmu lunak dan ilmu keras yang kemudian beliau korelasikan pada ranah keilmuan agama Hindu di representasikan pada sosok Dewi Saraswati dan Dewa Ganesha.

\section{PEMBAHASAN}

\section{Pengertian Konsep Ilmu dan Paradigma}

Pada pemaparan pendahuluan di atas termuat bahwa ilmu pengetahuan merupakan pengejawantahan pengetahuan dalam ruang yang lebih spesifik. Zaprulkan (2016: 13) merumuskan perbedaan mendasar antara pengetahuan dan ilmu, pengetahuan berasal dari istilah knowledge mengandung arti yang menjelaskan tentang adanya informasi, pemahaman dan keahlian yang diperoleh secara biasa melalui pengalaman atau pendidikan yang dialami dalam keseharian. Akan tetapi, pengetahuan sehari-hari atau "pengetahuan biasa" tersebut kebanyakan agak dangkal dan memiliki kekurangan antara lain kurang teratur, kurang dipersatukan, terlalu tercerai berai, tidak lengkap, dan fragmentasi saja, kebanyakan diperoleh secara insidensial, dipengaruhi oleh fantasi dan perasaan dan masih banyak memiliki kekeliruan. Demi terwujudnya pengetahuan yang lebih mendalam dan sistematis diperlukan usaha mensistematiskan pengetahuan itu dengan suatu 
metode. Tepat pada titik inilah, pengetahuan yang telah berkembang dengan menggunakan metode yang kebenarannya dapat dipertanggung jawabkan menjadi ilmu yang dalam bahasa Inggris disebut Science.

Science atau ilmu terkandung adanya pengetahuan yang pasti, lebih praktis, sistematis, metodik, iliah dan mencakup kebenaran umum mengenai objek studi yang lebih berifat fisis (natural) (Suhartono,2011:64), dalam perspektif Driyarkara, ada perbedaan signifikan antara knowledge dan science. Berbeda dengan pengetahuan biasa, ilmu tidak cukup hanya menetapkan kejadian-kejadian belaka atau memberikan penjelasan yang dangkal saja. Menurut Gie (2007: 85), ilmu atau science merupakan istilah yang memiliki makna ganda, dalam cakupannya yang pertama, ilmu merupakan istilah umum untuk menyebut segenap pengetahuan ilmiah yang dipandang sebagai satu kebulatan, jadi dalam arti yang pertama ini, ilmu mengacu pada ilmu seumumnya (science in general). Arti yang kedua dari ilmu, menunjuk pada masing-masing bidang pengetahuan ilmiah yang mempelajari sesuatu pokok soal tertentu

Lebih lanjut Gie merumuskan bahwa sebuah ilmu sekurang-kurangya mencakup tiga hal, yakni pengetahuan, aktivitas dan metode jika digambarkan, maka korelasi antara aktivitas, metode dan pengetahuan dapat digambarkan sebagai berikut :



Pengertian Ilmu sebagai pengetahuan, aktivitas dan metode selayaknya merupakan sebuah kesatuan logis yang mesti ada secara berurutan. Ilmu harus diusahakan dengan aktivitas manusia, aktivitas itu dilakukan dengan metode tertentu, dan akhirnya aktivitas metodis tersebut akan mendatangkan pengetahuan yang sistematis yaitu ilmu. 
Mengenai perkembangan sebuah ilmu, Thomas S. Kuhn menawarkan sebuah teori tentang bagaimana perubahan besar dalam ilmu terjadi. Narasi itu termuat dalam karyanya yang berjudul The Structure Of Scientific Revolution. Kuhn memandang sebuah ilmu di setiap waktu didominasi oleh sebuah paradigm tertentu (Ritzer, 2012: 1150). Sebuah paradigma berfungsi untuk membantu membedakan komunitas ilmiah satu dengan komunitas ilmiah lainnya, ia dapat digunakan untuk membedakan fisika dari kimia atau sosiologi dari psikologi. Bidang-bidang ilmiah tersebut memiliki paradigma yang berbeda beda.

Secara spesifik, Ritzer (2012: 1151) merumuskan definisi paradigma dari Thomas S. Kuhn sebagai berikut:

Sebuah paradigma adalah gambaran dasar dari pokok perhatian dalam sebuah ilmu. Ia berfungsi untuk mendefinisikan apa yang harus dikaji, pertanyaan apa yang harus ditanyakan, bagaimana untuk menanyakannya, dan kaidah-kaidah apa yang harus diikuti dalam menginterpreatsikan jawaban yang didapatkan. Paradigma adalah unit konsesnsus yang terluas di dalam sebuah ilmu dan berfungsi untuk membedakan sebuah komunitas ilmiah (atau subkomunitas) dari yang lain. Ia mencakup, mendefinisikan dan saling menghubungkan berbagai eksemplar, teori, metode, dan instrument yang ada di dalamnya.

Pengertian mengenai definisi paradigma di atas akan membantu pemaparan mengenai paradigma positivisme pada penjelasan berikutnya. Terminologi paradigma sendiri akan memberi batas dan framework pada pengkajian berikutnya.

\section{Ganesha sebagai Simbol Paradigma Positivisme}

Positivisme adalah aliran filsafat yang berpangkal dari fakta yang positif sesuatu yang diluar fakta atau kenyataan dikesampingkan dalam pembicaraan filsafat dan ilmu pengetahuan (Ihsan, 2010: 182). Tokoh aliran Positivisme yang terkenal adalah August Comte. Ia berpendapat bahwa indra itu amat penting dalam memperoleh pengetahuan, tetapi harus dipertajam dengan alat bantu dan diperkuat dengan eksperimen.

Jika mau dirunut, positivisme bukanlah suatu aliran yang khas berdiri sendiri. Ia hanya menyempurnakan empirisme dan rasionalisme yang bekerja sama, dengan kata lain positivisme menyempurnakan metode ilmiah dengan memasukkan perlunya eksperimen dengan ukuran-ukuran (Ihsan, 2010: 183). August Comte 
dalam Ihsan (2010: 184) merumuskan adanya tahapan atau zaman yang dilalui oleh pikiran manusia yaitu

1. Zaman teologis, zaman dimana manusia percaya bahwa dibelakang gejala-gejala alam, terdapat kuasa adikodrati yang mengatur hal tersebut.

2. Zaman metafisis, kekuatan-kekuatan yang adikodrati diganti dengan ketentuan abstrak.

3. Zaman positif, yaitu ketika orang tidak lagi berusaha mencapai pengetahuan tentang yang mutlak baik teologis, maupun metafisis melainkan telah berusaha mendapatkan hukum-hukum dari fakta-fakta yang didapatinya dengan pengamatan dan akalnya.

Atmaja (2014) mengasosiasikan paradigma positivisme ini dengan sosok Dewa Ganesha, hal ini merujuk pada terdapatnya dua sosok Ilmu pengetahuan dalam Hindu yaitu Dewa Ganesha dan Dewi Saraswati. Atmaja (2014: 53) merumuskan bahwasanya Dewa Ganesha merupakan simbol dari paradigma positivisme, hal ini merujuk pada jenis kelamin Dewa Ganesha yang merupakan maskulin sehingga terasosiasi dengan ilmu pengetahuan alam atau ilmu keras (hard science).

Lebih lanjut Atmaja menyatakan bahwa selain dari sisi jenis kelamin, perumusan bahwa Dewa Ganesha merupakan simbol dari paradigma positivisme dapat ditelusuri melalui nama Beliau yaitu Gana, rumusan ini muncul dari hasil wawancaranya dengan Dr. Wayan Sukayasa yang menyatakan Gana memiliki arti mengukur, sehingga hal ini sangat cocok dan sangat mendukung asumsi Ganesha selaku simbol paradigma positivisme, walaupun jika ditelusuri dalam kamus Jawa Kuna, kata Gana sebenarnya memiliki arti “jumlah” (Zoetmulder, 2004: 270) namun perbedan arti antara "ukur" dan "jumlah" tidaklah secara signifikan mengurangi asumsi tersebut dikarenakan kata "ukur" dan "jumlah" terkorelasi dalam paradigma ilmu keras atau hard science.

\section{Dimensi Ontologi, Epistemologi dan Aksiologi dari Paradigma Positivisme}

Kata dimensi digunakan untuk menunjukkan sudut pandang terhadap sesuatu, baik itu dari sisi substansi, cara memperoleh hingga manfaatnya.

\section{a) Ontologi}

Menurut Ihsan (2010: 223) istilah "ontology" berasal dari kata Yunani "onta" yang berarti "sesuatu yang sungguh-sungguh ada", "kenyataan yang sesungguhnya" dan "logos" yang berarti "studi tentang". Jadi ontologi adalah 
studi yang membahas sesuatu yang ada. Lorens Bagus (2002: 746-747) menjelaskan beberapa terminologi mengenai ontologi sebagai berikut:

1. Studi tentang ciri-ciri esensial dari Yang ada.

2. Cabang filsafat yang menggeluti tata dan struktur realitas dalam arti luas.

3. Cabang filsafat yang mencoba melukiskan hakikat Ada yang terkahir, menunjukkan bahwa segala sesuatu tergantung pada-Nya.

4. Cabang filsafat yang menyelidiki status realitas suatu hal.

Secara umum, ontologi merupakan sebuah studi terhadap suatu realitas yang Ada atau jika ditarik kepada ranah studi filsafat, ontologi dapat dikategorikan sebuah objek material dari filsafat. Hal ini berkenaan dengan objek material filsafat yang disebut sebagai segala sesuatu yang Ada dan bahkan mungkin yang akan Ada (Donder, 2010: 144).

Berkenaan dengan ontologi dalam paradigma positivisme, dapat dikatakan bahwa dimensi ontologi adalah segala objek materi berwujud bendabenda dan atau gejala-gejala kealaman, bisa juga gejala sosial atau perilaku manusia yang diberlakukan sebagai gejala alam.

\section{b) Dimensi Epistemologi}

Istilah epistemologi berasal dari bahasa Yunani "episteme" yang artinya pengetahuan, dan "logos" yang artinya teori. Jadi epistemologi adalah dimensi filsafat yang mempelajari asal mula, sumber, manfaat, dan sahihnya pengetahuan. Secara sederhana disebutkan saja sebagai cara mempelajari, mengembangkan, dan memanfaatkan ilmu bagi kemaslahatan manusia (Ihsan, 2010: 225).

Jika berbicara mengenai epistemologi pada ranah, ruang lingkup paradigma Positivisme, yang mana telah disepakati bahwa positivisme adalah ilmu keras yang berkaitan dengan alam (sains) maka terdapat beberapa cara dalam mengkaji positivisme menurut Zaprulkhan (2016: 73) yaitu:

1. Empirisme: merupakan suatu doktrin filsafat yang menekankan peranan pengalaman dalam memperoleh pengetahuan dan mengecilkan peranan akal.

2. Rasionalisme: pandangan bahwa kita mengetahui apa yang kita pikirkan dan akal mempunyai kemampuan untuk mengungkapkan kebenaran dengan diri sendiri, atau pengetahuan itu diperoleh dengan membandingkan ide dengan ide. 
3. Kritisisme: pandangan yang memandang perlunya korelasi antar realitas empiris dan proses penalaran dalam mengkontruksi pengetahuan.

4. Intuisionalisme: pandangan yang mengklaim bahwa realitas dunia secara hakiki bisa dipahami melalui intuisi.

Pemikiran filsafat barat dalam ranah epistemologi telah mengakar pada tiap filsuf di dunia, tanpa sadar kita sebagai masyarakat Hindu sebenarnya juga memiliki metode yang hampir bahkan mirip dalam hal mencari kebenaran pada ajaran Nyàya Darsana yaitu:

1. Praktyaksa Pramàna (Pengamatan langsung): memberikan pengetahuan kepada kita tentang objek-objek yang diamati.

2. Anumàna Pramàna (Penyimpulan): proses dimana setelah indra kita mendapatkan informasi melalui Praktyaksa Pramàna, maka akan ada proses penyimpulan demi mewujudkan analisis yang lebih mendalam.

3. Upamàna Pramàna: cara pengamatan dengan membandingkan kesamaankesamaan yang mungkin terjadi atau terdapat di dalam objek yang diamati dengan objek yang telah ada sebelumnya.

4. Sabda Pramàna: Pengetahuan yang diperoleh melalui kesaksian (sabda) dari seseorang yang dapat dipercaya kata-katanya ataupun dari naskahnaskah yang diakui kebenarannya, sehingga dalam hal ini terdapat 2 jenis kesaksian, yaitu: a) Laukika Sabda (bentuk kesaksian yang bersal dari orang yang dapat dipercaya), dan b) Vaidika sabda (bentuk kesaksian yang didasarkan pada naskah-naskah suci Veda Sruti, yang merupakan sabda Brahman yang tidak mungkin salah) (Maswinara, 1999 : 127-134).

\section{c) Dimensi Aksiologi}

Bagus (2002: 33) merumuskan secara etimologis, aksiologi berasal dari bahasa Yunani "axios" yang berarti layak atau pantas, dan "logos" yang berarti ilmu atau studi. Berdasarkan pengertian tersebut setidaknya terdapat beberapa makna terminologi aksiologi yaitu:

1. Aksiologis merupakan analisis nilai-nilai.

2. Aksiologis merupakan studi menyangkut teori umum tentang nilai atau suatu studi yang menyangkut segala yang bernilai.

3. Aksiologi adalah studi filosofi tentang hakikat-hakikat nilai.

Jika merujuk pada terminologi "paradigma" selaku frame work suatu ilmu maka dapat dijelaskan bahwa aksiologi dari paradigma positivisme memiliki dua nilai, yaitu positif dan negatif. Berimplikasi baik ketika kehadiran ilmu tersebut dalam memprediksi, mencegah, mengatasi bahkan dalam upaya merehabilitasi fenomena-fenomena ke-alaman, seperti fenomena geologi, 
fenomena kesehatan. Namun, juga dapat menjadi bencana jika tidak dipergunakan dengan baik seperti penggunaan senjata biologis dalam perang, bom rakitan bahkan racun yang diracik bukan untuk kepentingan orang banyak.

\section{PENUTUP}

Ilmu merupakan serangkaian pengetahuan yang dikerjakan secara metodis sehingga menjadi suatu kajian yang tersistem. Dewa Ganesha dapat disimbolkan menjadi representasi dari ilmu pengetahuan keras atau hard Science. Dimensi ontologi dari paradigma positivisme adalah segala aspek yang sifat materialnya berada di alam, dimensi epistemologinya adalah beberapa cara pandang seperti empirisme, rasionalisme, kritisime hingga intuisionisme. Selain pandangan empirisme barat, sesungguhnya dalam tradisi timur juga memiliki epistemologi yang hampir sama yaitu Praktyaksa Pramàna, Anumàna Pramàna, Upamàna Pramàna dan Sabda Pramàna. Dimensi Aksiologis pada paradigma positivisme memiliki 2 nilai, dapat bernilai positif dan dapat pula bernilai negatif. Ia akan bernilai positif selama mampu bermanfaat bagi banyak orang, dan tentu saja akan bernilai negatif selama itu merugikan manusia.

\section{DAFTAR PUSTAKA}

Atmaja, Nengah bawa. 2014. Saraswati dan Ganesha Sebagai Simbol paradigma interpretativisme dan positivisme. Pustaka Larasan: Denpasar

Bagus, Lorens.2002 Kamus Filsafat. Gramedia Pustaka Utama: Jakarta

Donder, I Ketut. 2010. Filsafat Ilmu. Paramita: Surabaya

Gie, The Liang. 2007. Pengantar Filsafat Ilmu. Liberty: Jakarta

Ihsan, Fuad. 2010. Filsafat Ilmu. Rineka Cipta: Jakarta

Maswinara, I Wayan. 1999. Sistem Filsafat Hindu. Paramita: Surabaya

Ritzer, George. 2012. Teori Sosiologi dari Sosiologi Klasik Sampai Perkembangan Terakhir Postmoder. Pustaka Pelajar: Yogyakarta

Zaprulkhan. 2016. Filssafat Ilmu. Rajawali Press: Jakarta

Zoetmulder. 2004 : Kamus Jawa Kuna. PT Gramedia Pustaka Utama: Jakarta 